[12] Mémorial A n 143 de 2016 [Amendment A to the Law n 143 2016]. Journal officiel du GrandDuché de Luxembourg [Official newspaper of the Grand Duchy of Luxembourg]. Available at: http://legilux. public.lu/eli/etat/leg/memorial/2016/143?highlight=enseignement $\% 22$ sup $\% 20 \% \mathrm{C} 3 \% 20 \% \mathrm{~A} 9$ rieur

[13] National plan for smart, sustainable and inclusive growth 2020 (2016). Luxembourg.

[14] National Reforms in Vocational Education and Training and Adult Learning. Luxembourg. Available at: https://webgate.ec.europa.eu/fpfis/mwikis/eurydice/index.php/Luxembourg:National_Reforms_in_Vocational_Education_and_Training_and_Adult_Learning

\title{
VALUE GAPS IN THE PLANETARY MATRIX OF THE WORLD COMMUNITY AS A LIMITROPHE OF WAR AND PEACE
}

Bohdan Kalinichenko

Department of Civil Service, Public Administration and Political Science

Bohdan Khmelnitsky National University of Cherkasy

81 Shevchenko blvd., Cherkasy, Ukraine, 18031

555tvukraine@vu.cdu.edu.ua

\begin{abstract}
The article describes the problem of spontaneous transformation of the planetary matrix of the social world, moving from the cell to the network structure, resulting not only in the changes of the world system of the planetary community, the shapes of national states are melting out gradually, the need for cosmopolitan world perception and thinking of the political elite arises, the managing processes come into the picture, hybrid planetary policy is formed, and finally, qualitatively new conflict forms and even hybrid wars appear. With the change in the planetary matrix structure, there are several fundamental changes in the life-plan of a planetary human being, since the fundamentally different segments of archetypes are activated in the world community's subconsciousness, the values-semantic substrates are mixed in the consciousness, and completely different logical schemes and algorithms of influence on a person are activated in the noosphere. At the same time, this means that in the sphere of national powers the emphasis of state policy, state regulation and public administration tends to shift from the territorial horizon into the plane of regulation of world planetary processes. This tendency also transfers the focus of their organizational efforts from the national and state levels to the political space of interstate and supra-state entities. The most intense points of relations between the actors of the modern integral process are the so-called limitrophes and frontiers.
\end{abstract}

Keywords: civilization, matrix, transformation, cell structure, network, fault, cosmopolitan consciousness, limitrophe, frontier, hybrid war.

\section{Introduction}

Lately, the modern planetary world has been in the state of actual unsolemn permanent war. Today, it has a different degree of cruelty in more than forty locations on the planet. It acquires qualitatively new features, for example, becomes hybrid when the boundary between "us" and "them" actually disappears. The confrontation moves into the consciousness of the average person, which generates the fear and uncertainty of the entire peoples in the future on a mass scale.

Therefore, it became an acute practical and theoretical problem at the beginning of the XXI century. And it is related to the fact that this is not only about the lost lives of dozens, if not hundreds of thousands of people, and the huge loss of material wealth of the peoples, who have been building a practical basis for their own livelihoods for decades, but also about our theoretical and practical misunderstanding of what is happening with the consciousness of the planetary humanity, which, under the pressure of the generally accepted processes of globalization, informatization and significant increase in the capacity of international communication networks, must become more and more planetary, i. e., one that understands the common problems of the world community and is aimed at their positive solution. 
Unfortunately, in practice, we are observing quite the opposite. The world begins intensive glocalization and small groups of carriers of anti-planetary ideas and religious fanatics are already beginning to enter massively the confrontation. What the outbreak of attacks on women in Europe by the so-called refugees from the Arab world is worth.

Therefore, the modern political science faces an acute social problem of explaining the causes and sources of increasing tension in the modern planetary world not so much in terms of the subjective factors behavior, i.e., by the reference to the mental difference of the aggressive action carriers, but using the theoretical analysis of the objective source of political tension growth, which constantly maintains the thirst for war in people and rulers, and delays peace and harmony between peoples for an indefinite period, most likely till the very end of the XXI century. From the outside it looks as if globalization leads to an increase in political tension between countries, and it serves as the basis for military conflicts that have generated even a qualitatively new form - a hybrid war. But everything in its time. Problems of globalization and globalization consciousness of the humanity have recently been studied in many scientific works. It this case it is enough to refer to the works of the classics of the humanities, Beck Ulrich, Beisheim Otto, Giddens Anthony, Harvey Norman, Held Martin etc. Let us look at the evaluation of the causes and consequences of the globalization made by Ulrich Beck in his famous works "What Is Globalization" (2001), "Power and Its Opponents in the Globalization Era. New World-Political Economy" (2007) [1, 2].

Based on the study of this problem, U. Beck came to the conclusion that the misunderstanding between the researchers who in the public debate defined the concept of "globalization" as the word that makes no sense, is over; others, by contrast, raise it to a new level of the fate of the world community, which has to solve all its problems at the expense of the collective cooperation of peoples among themselves.

Further, U. Beck points out that the discussion gradually moved to the practical plane. And according to his estimations, two methodological approaches were formed. The former comprehends and explores globalization in the spirit of growing interconnectedness, that is, in the spirit of an increasing number of interlacings, interdependencies, international flows, identities and social ties.

The second approach emphasizes the "abolition of space by time" due to new communication means. "People tend to conduct business internationally, work, love, marry, live, travel, consume, eat, educate children in an international spirit, exist in a generalized, nobody's space of television and the Internet; political identities and passions also no longer obey the commandments of the national monogamy of loyalty. Globalization is already conceived not as in the first approach - the growing interdependence, the continued existence of national-state public spaces, but as the internal globalization of these spaces themselves" [1, p. 9].

U. Beck in the preface to the work "The Power and Its Opponents in the Globalization Era. New World-Political Economy" notes that "... picking up these theses and at the same time making a significant step forward ... raises and develops the idea of globalization as a historical transformation (highlighted by B. K.)" [1, p. 9]. He then draws a conclusion: “... what so far played the leading role in the view of the world distinction between national and international is dissipated in the still vaguely defined power space of the worldwide internal policy" [1, p. 9]. The question arises from what our world moves and where it is moving?

Therefore, "the key problem of the present "procedural moment" is precisely the fact that many people (politicians, experts, scholars, journalists) keep on treating the current state as something temporary. They often perceive and treat it as something that is a "deviation from the norm" or simply a "transit state" to a fundamentally different "better future". Moreover, this is the opinion of even those, who have destroyed this world order that seemed unyielding a few years ago... " [3, p. 7].

What kind of inhuman power creates the attraction of national centers of political power to the voluntary implementation of a mutually agreed worldwide internal policy. The answer to this question is the purpose of this article.

\section{Aim of research}

Identify the reasons why the national centers of political power are forcing voluntarily to establish a mutually agreed global internal order. 


\section{Materials and methods}

To carry out this research study we have looked into views of well-known political scientists and philosophers on the issues of interest to us. The toolkit used in this study includes custom methods for obtaining knowledge such as observation, analysis, synthesis, comparison, deduction and induction.

\section{Result and discussion}

The answer to the question, what this "historical transformation" process is, becomes possible if we substantiate the hypothesis of the existence of a planetary value-semantic matrix serving its social and political-organizational space, which includes the national power centers. In other words, the problem arises when the existing planetary value-semantic matrix does not provide for productive life activities and the development of the world community by means of functioning in the vertical space of universal, regional and ethnic-national values, distributed in a horizontal space on nine glocalized branches of the planetary civilization.

The planetary matrix, which has a value-semantic filling, as the nervous system serves the life activity of the human beings, so it serves the homeostasis and homeorhesis of the planetary social organism. At the same time, the semantic component in the self-regulation system of the socio-political development of a planetary whole enters into effect and provides for its innovative development, and the value, on the contrary, keeps the social system in a given range of possible transformation and does not let it leave those limits.

The ontological analysis brings us to the understanding that the modern planetary world is arranged in accordance with the principle of a cell structure, i. e., each national state is a capsule/ monad with its values, the mentality of the population, and the willingness to protect its own existence when a neighbor makes an attempt to encroach on its national space. In this case the state independence and sovereignty are naturally the main signs of the state power and independence. This is supported by all components of the humanitarian sphere of the national state - from philosophy, religion, culture, propaganda and education to legal and judicial protection. So, a national statehood cell is based on the monad existence of an ethnic group and an average person in terms of value-semantic activity of the national society.

Thus, during the previous civilization development, the peoples, who were able to create a state, created an artificial, comfortable world for themselves, in which they separated themselves from all obscure, unacceptable in terms of their religion, philosophy, ethics and law.

Such a spatial limitation of value-semantic meaning in previous decades was forced and can be explained by the attributive properties of an average person.

This affects not only the existential but also the epistemological phenomenon of human presence in the construction of the world. The fact is that in natural-essential existence a person noumenally experiences an information load of one million bits every minute. However, a human being is able to master only 50 thousand bits of information per minute. Therefore, a person perceives reality selectively, according to the parameters of their needs and life orientations. Hence the objective need to encapsulate the living space of the peoples in previous eras arises. For this purpose the world community needs to master the model forms of the planetary life presentation, as, for example, politics, art, science or religion do it.

This is fundamentally possible, since in the modern era the picture began to change dramatically due to the emergence of a global information network Internet, which operates on satellite communications, uses computer channels, a new computer infrastructure of collective planetary thinking of the world community. It also creates an opportunity for dialogue on the planetary scale on a collective basis. Thus, not only the "world brain", which H.Wells has dreamed of, matures, but also other elements of the new world order become mature: world power, world government, global civil society, world market, planetary identity, global knowledge, global education, world culture, etc.

The world becomes fluctuating despite the fact that the human existence is constituted phenomenally in a certain value-adaptive option. As S. Krymskyi notes, that in this case "the reality of the humane environment loses the features of objective spontaneity. What is called "sober reality" is in fact a compromise, a collage of utopia and life. Otherwise, as shown by E. Zamyatin in his 
essay "Herbert Wells", the reality would be not sober, but crazy. Apparently, if we once determine how the world's elements control the human being, this day would be the last day of human existence. That is why our civilization builds its own world, acceptable for the spirit of the era, not always successful in its implementation, but necessarily an alternative to the challenges of the abyss" [4, p. 30].

Of course, the value component of the spiritual universe "summoned" such localized value-semantic fields to more complex segments, called the branches of civilization. Their functioning is provided for the basis of the geocultural values. Therefore, the planetary world today "broke down" into nine segments.

V. O. Nikytenko in the study of geocultural values in the context of contemporary world development gives the segmentation of the planetary value-semantic field [5]. The geocultural values are, according to this author's definition, what the feelings of people force to recognize as prevailing over the existing, which should be sought, contemplated, treated with respect and recognition. They can be classified both vertically and horizontally. In the vertical section - this is their division into world, regional and ethnic-national geovalues. V. O. Nikytenko distributes them horizontally according to the nine branches of the civilization division of the planetary community, namely: American, European, Arabic-Islamic, Confucian, Orthodox-Slavic, Hindu-Indian, Japanese, Latin American and African regional sectors of geoculture [5].

Each state in the course of cultural and historical development has developed its own algorithm of existence and has a positive practice of political leadership of the society life. The core of the livelihood of the specific peoples, localized in the cell, is a major need that is protected by political power up to the use of military force. For example, according to V. O. Nikytenko, the focus of the American nation is the world domination, European - humanism, Arab-Islamic - religion, Chinese - the continuation of the genus, Orthodox-Slavic - the production of spirituality, Hindu-Indian - preservation of caste hierarchy, Japanese - work, Latin American - search for identity and affirmation of their own personality, African - solving food problems [5].

At the junction of the national states, the neighboring zones have emerged and function, for example, the Hungarians or the Poles in Ukraine. This means that each such structural unit or cell in the value-semantic matrix of the planet has its own filling and is a potential conflict zone in relation to its neighbors.

A special term appeared in the political science - frontier - "border", territory on the border of two different societies. It is a transition zone, which is generally poorly integrated into the state structures and dynamic in nature, is characterized by high interactions between different, often hostile cultures.

Moreover, a line of value fracture, called limitrophe (from lat. limitrophus - boundary) is formed in the cultural-worldview space between the specific groups of countries. This geopolitical concept first appeared in the Ancient Rome. The concept of "civilizational interworlds" or limitrophe, has an important methodological significance in civilizational zoning and for the explanation of ethnic and interstate conflicts origins and even many numerical local small and large wars. This concept is related to the problems of the boundaries between civilizations and describes territories that potentially have an element of conflict (historical, ethnic, cultural, etc.) and helps to resolve such conflicts.

The civilizational approach is rather wide-spread in country study researches and the concept of "limitrophe" plays an important role in it, as it is related to such widely used country study concepts as "territory", "state", "interstate space", "civilization inter-worlds".

The study of the Great Limitrophe is closely intertwined with the problems of research in political geography and geopolitics. V. Tsymburskyi considers the belt of limitrophes adjacent to Russia as "a giant limitrophe, which, cutting Europe and Asia, separates Russia and gives it the features of a peculiar island within the continent".

V. Tsymburskyi, for example, argues that "the large inter-civilization belt (Limitrophe), which extends from the Baltic through Eastern Europe and covers the Caucasus, post-Soviet Central Asia and the so-called old Tibet-Xinjiang-Mongolian Central Asia, ends in Korea." He states 
that this "belt of territories-streams separates Russia from power centers established on the platforms of other civilizations" [6].

In his opinion, the large limitrophe stretches across the continent from Poland and the Baltic to Pamir and Tian Shan, covering Eastern Europe with the Balkans, the Caucasus and the "new", i. e. post-Soviet, Central Asia. From the cultural and geographic point of view, this belt, or the Great Limitrophe, is formed by the transitional peripheries of all civilizations of the Old World: Romano-Germanic (Western Europe), Arab-Iranian (Middle East), Russian, Chinese, and Indian. It finds its natural extension in the Turkic-Mongolian lands along the junction of the platforms of China and Russia, branches in the Tibet and completion in the Korean peninsula. V. Tsymburskyi believes that most likely it will be on the Great Limitrophe that the most important military-strategic and geoeconomic events of the early twenty-first century will take place [6].

S. Khatuntsev has a slightly different view on the problem of the Great Limitrophe. He describes the Great Limitrophe as a line stretching from Finland through the Baltic, Poland and Western Ukraine, further through Moldova and the Crimean mountains - to Transcaucasia and Anatolia. After the Caspian Sea, it includes parts of Turkmenistan, Afghanistan, Pakistan, Kashmir, Uighur to finally, through Mongolia, Manchuria and Primorsky Krai, it reaches the Kuril Ridge, the Aleutian Islands and Alaska [7].

Unlike S. Hatuntsev, V. Tsymburskyi includes in the Great Limitrophe a much larger part of Eastern Europe and the entire region of deserts and semi-deserts in the north of the Pamir, but does not include Afghanistan and Pakistan. In addition, he does not see any limitrophic spaces in the Pacific Ocean region.

But at the beginning of the XXI century, the picture began to change dramatically due to the globalization and informatization mechanisms. The cell structure of the planetary matrix transformed into the network. And when the morphological structure of the planet came into motion, not only the state structures shifted, but groups of countries began to change their borders and political imperatives. They are forced to build new political defense mechanisms. This can be seen from the example of such intergovernmental groups as the EU and BRIC.

Regional authorities, trying to protect the priorities of national development, are constantly in the state of tension with other members of the planetary political sphere. Constantly protecting their national values they cannot respond to the changes in the value-semantic matrix of the planet in a timely manner and in full. Consequently, contradictions are constantly accumulated and naturally grow into a crisis.

The process of self-destruction of the planetary world under the pressure of the planetary matrix transformation toward the network structure is so intense that, according to the forecasts of some analysts, the countries die as relatively well-established and independent structures. For example, at the Synergy Global Forum, Kiel Nordstrem, a professor at the Swedish School of Economics, gave a forecast that in 50 years instead of 218 countries there will be 600 cities [8]. He further notes that "in 25 years there will not be, for example, Austria, because Austria is already Vienna - and some small towns nearby. This will happen due to a change in the system of information perception, the development of transport and technology in general" [8].

Thus, with the change in the planetary matrix structure, there are several fundamental changes in the life-plan of a planetary human being, since the fundamentally different segments of archetypes are activated in the world community's subconsciousness, the values-semantic substrates are mixed in the consciousness, and completely different logical schemes and algorithms of influence on a person are activated in the noosphere. At the same time, this means that in the sphere of national powers the emphasis of state policy, state regulation and public administration tends to shift from the territorial horizon into the plane of regulation of world planetary processes. This tendency also transfers the focus of their organizational efforts from the national and state levels to the political space of interstate and supra-state entities.

Such tectonic shift generates new forms of military conflicts and even wars. One of them is the hybrid war, informational war, cyberwar, etc. UN Secretary-General Antonio Guterres believes, for example, that the world has faced the need to establish a permissible framework for interstate cyberattacks. He made this announcement on February 16, 2018, during his speech at 
the 54th Munich Security Conference, a "European Truth" correspondent report from Munich. He reminded that mutual strikes in cyberspace have become a reality. "The time has come to talk about the international legal framework for cyberwar," UN Secretary General said [9]. He suggested starting a discussion on this issue at the UN General Assembly site. As it is known, there are international rules of armed conflicts with similar names. "Laws and customs of war" were enshrined in a number of international conventions more than 100 years ago, which since then have been modified many times. Their violation is an international crime.

The most intense points of relations between the actors of the modern integral process are the so-called limitrophes and frontiers. Therefore nowadays the humanity faces the challenge of hybrid wars, whether we like it or not. It is these wars that generate a new hybrid world, or to be more accurate, a hybrid world order. And we must respond adequately to this challenge, taking social planetary reality as it is. Since "there is nothing more constant in the world than inconstancy", - J. Swift wrote [10, p. 167].

\section{Conclusions}

1. The globalization and informatization mechanisms change the existing value-semantic matrix of the life-structure of the planetary community from the cell-type to the network type, which entails a lot of morphological and functional consequences. Borders between national states disappear, and the value-semantic determinants of the life-style of the peoples acquire vague outlines.

2. The priorities of the national policy of each separate branch of civilization are gradually transforming into the solution the needs of the planetary nature.

3. We observe how the emphasis of state policy, state regulation and state administration from the territorial horizon shifts to the regulation of the world planetary processes.

4. The formation of a hybrid world immanently carries not only new forms of life-style and communications, but also hybrid forms of confrontation, for example, hybrid conflicts and even hybrid wars.

\section{References}

[1] Beck, U. (2007). Power and Its Opponents in the Globalization Era. New World-Political Economy. Moscow: Progress-Traditsiya; Publishing House "Territoriya Budushchego", 464.

[2] Beck, U. (2001). What Is Globalization? Moscow: Progress-Traditsiya, 304.

[3] Gorbulin, V. P. (Ed.) (2017). World Hybrid War: Ukrainian Front. Kyiv: NISD, 496.

[4] Krymskyi, S. (2006). Philisophical Senses Explication. Moscow: Ideya-Press, 240.

[5] Nikytenko, V. O. (2013). Geocultural Values under the Conditions of the Modern Global Development: Social and Philosophic Planes. Humanitarian Newsletter of Zaporizhya State Engineering Academy, 54, 266-280.

[6] Tsymburskyi, V. L. (1999). Russia - the Land Beyond the Great Limitrophe: Civilization and its Geopolitics. Moscow: URSS, 144.

[7] Khatuntsev, S. V. (1994). New Vision of the Civilizations Development and Classification on Cultural-Historical Communities Civilizational Approach to History: Development Problems Issues and Perspectives. Part 1. Voronezh, 71-73.

[8] Nordstrem, K. In 50 years 600 cities will replace 218 countries. Available at: http://hvylya.net/ analytics/society/kell-nordstrem-cherez-50-let-vmesto-218-stran-budet-600-gorodov.html

[9] UN Secretary General: the time has come to set the rules for cyberwar. Available at: http://www. eurointegration.com.ua/news/2018/02/16/7077641/

[10] Kalenych, V. (2017). Text formation potential of quotations in newspaper articles. Scientific notes of the Vinnitsa State Pedagogical University named after Mikhail Kotsiubynsky. Series: Philology (Linguistics), 24, 165-171. 